Wijayanama, C., Ranjani, R.P.C., Mohan, D.U., KJM, 2021, 10 (01)

\title{
Can Service Learning enhance Graduate Capital? Evidence from Sri Lankan State Universities
}

\author{
Wijayanama C. ${ }^{1}$, Ranjani R.P.C. ${ }^{2}$, Mohan D.U. ${ }^{3}$ \\ 1,2,3 Faculty of Commerce and Management Studies, University of Kelaniya, Sri Lanka \\ ${ }^{1}$ wijayanama@gmail.com, ${ }^{2}$ chitra@kln.ac.lk, ${ }^{3}$ mohanudaya395@gmail.com
}

\begin{abstract}
Employability of graduates has been a topic of high interest among graduates, academics, employers and economists alike for decades. Researchers argue that the responsibility of preparing graduates for their first job roles, has not been adequately owned by the universities nor the employers. The graduates themselves, give less attention to the issue and usually ill prepared for their first job roles. Service Learning (SL) is a futuristic andragogical strategy that changes the receiver and the giver of the service. In this study, the researcher examines how SL can be adopted as an enhancer of employability potential for graduates. Since the SL is new to the academic world in general and also to the Sri Lankan education system, this inductive study adopted the Grounded Case Study method using theoretical sampling to study the influence of SL as a strategy for enhancing graduate employability potential - Graduate Capital (GC) in state universities of Sri Lanka. The findings of the study include the features of SL practiced in Sri Lanka, GC attributes and the extent of enhancements of GC attributes due to partaking in SL program. The current study concludes that SL provides overall improvement to GC attributes.
\end{abstract}

Keywords: Employability, Graduate Capital, Grounded Case Study, Service Learning

Copyright: (C) 2021 Wijayanama, C., Ranjani, R.P.C., Mohan, D.U. This is an open access article distributed under the Creative Commons Attribution License, which permits unrestricted use, distribution, and reproduction in any medium, provided the original work is properly cited.

Correspondence: wijayanama@gmail.com

ORCID of authors: Wijayanama, C. (1D https://orcid.org/0000-0003-2030-6309

Ranjani, R.P.C. (D) https://orcid.org/0000-0001-5823-3200

Mohan, D.U. (D) https://orcid.org/0000-0002-4617-1409

DOI: http://doi.org/10.4038/kjm.v10i1.7629 


\section{Introduction}

Researchers argue that responsibility of developing employable graduate gravitates around with the educators (Harvey, 2001), or employers (Fejes, 2010) or the graduates (Garsten \& Jacobson, 2004). Graduates struggle to transition into their first jobs despite of the main function of education being meeting the needs of the labour market (Bathmaker, Ingram, \& Waller, 2013). Addressing this issue seems to reside outside the main focus of university education in Sri Lanka as Sri Lankan tertiary education system is focused more on imparting academic knowledge to the students rather than focusing on employability (Ariyawansa, 2008). Whilst the educators seem to have been making conscious efforts to take the university education system out of the traditional frame (Bringle \& Hatcher, 1999), the andragogical aspects that are closer to the adult students' learning needs were found in SL.

Sri Lanka has a highly competitive entrance exam for the state universities and the best performing students at this examination only around $20 \%$ of the qualified students (University Grants Commission, 2018) enter into these universities. Whilst it can be argued that the percentage of students selected for education at state universities are too few, such a group of student0073 forms a solid base for developing competent contributors in key roles of organizations they eventually find the employment in. This also supports the contribution of the respective organizations for the national economy.

Sri Lanka has had a rich Buddhist templebased education system prior to colonization. British colonial rulers established university education in Sri Lanka in 1921. The primary objective of establishing the university education in Sri Lanka was to bridge the gap between the people and British administrators by creating an elite class of officers (Jayasundara, 2014). Even though the Sri Lankan university education system has taken many positive strides since then, including government sponsored university education since 1945 and thus recording a significantly high participation rate among other developing nations (Wickramasinghe, 2018), the relatively high rate of unemployment among graduates has been a concern for decades. The university education system is also accused of being unable to modify the traditional content of education to the needs of the job market (Ariyawansa, 2008). Since the liberalization of the economy in Sri Lanka towards an open economy in 1978, the private sector has been the driving force of the economy. Therefore, the universities are expected to understand and develop the employability attributes of the students that support them in getting employed in the private sector.

Examining the applicability of SL in Sri Lankan tertiary education system is important due to two reasons. Firstly, Sri Lanka has committed that by 2030 it will achieve the Sustainability Development Goal (SDG 4.4) that stands for substantially achieving the relevant skills for decent jobs. Awareness on demand side factors for employability like relevant competencies and attributes should be explored. Study on GC serves this purpose. On the other hand, despite many involvements by the university students in serving community needs, such activities do not target skill development in a structured manner. Service Learning that is new to the Sri Lankan university education system addresses student development in ways cognitive, behavioral, emotional a social outcome (Simonet, 2008). As it would be useful to understand SL's influence on the students' competency building, outcome of this study would be significant for educators, and the policymakers of education.

Kolb's Intuitive Learning Theory (1984) which many SL researches are anchored on is challenged by other researchers like Fenwick (2003) as Kolb's Intuitive Learning Theory (ILT) doesn't adequately provide contextual 
and social aspects of experiential learning. On the other hand, Mezirow's conceptual framework (Mezirow, 1990) is regarded as a young theory by other researchers like Cranton (2013). Therefore, further testing of Kolb's ILT is required. Empirically, concerns on content validity and reliability of SL studies have been raised (Celio, Dulrlak \& Dymnicki, 2011). Studies on SL are resource hungry and therefore, usually limited to smaller sample sizes therefore, certain regression analysis cannot be carried out. Moreover, quality issues such as students not understanding how the feedback tools are used have been found (Joseph, Stone, Grantham, Harmancioglu, \& Ibrahim, 2007).

In this study, the researcher explores key attributes that employers look for in hiring university graduates. These attributes would be the GC attributes for selected Sri Lankan employers. Thereafter, the researcher goes on to examine whether SL helps to develop the GC attributes.

The main purpose of this study is to examine how SL can be adopted as an enhancer of employability potential of graduates and to build a theoretical framework related to same. The outcomes of this study are expected to contribute to developing a GC model that helps the recruiters and the talent developers alike in graduate selection and development. Secondly, the universities would be able to use the same GC model to provide career guidance for the students. The outcome of the current study can also be used to upgrade university course curricula to support the employability of graduates.

\section{Literature Review}

\section{What makes graduates employable?}

Despite earning a good degree, many of the fresh graduates struggle to find the job they desire (Begal \& Simon, 2008; Mourshed, Patel \& Suder, 2014). Researchers argue that the academic qualifications alone don't help the students' employability (Brown, Hesketh, \& Williams, 2003; Finch, Hamilton, \& Zehner, 2013; Tomlinson, 2017). They argue that soft skills or employability skills must adequately complement academic qualifications for improving employability potential. More recent studies by Tomlinson (2017) suggests that the employability skills go even beyond soft skills to be acquired through lived experience that is more dynamic and interactive.

The definition of employability has been varying among theorists due to its complex nature. While Hillage and Pollard (1998) defined it as someone's ability to find her first job McQuaid, Green and Danson, (2005) defined it as the ability of unemployed persons to find a job while an employed person finds a better job. Paadi (2014) explains that employability influences three theories: Talcott Parson's Consensus Theory that is linked to norms and shared beliefs of the society; Conflict theory of Karl Marx, who elaborated how the finite resources of the world drive towards eternal conflict; and Human Capital Theory of Becker which is more "General purpose and firm-specific" (Gibbon \& Waldman, 2004, p. 206) where any stock of skills, knowledge or competencies are believed to be contributing towards the productivity of an individual.

According to the review by Sumanasiri, Yajid and Khathibi (2015), studies on employability have evolved from "Skills" approach of Cotton (1993) to "Skills Plus" approach of Knight and Yorke (2002). Skills approach discusses basic, higher order and affective skills and Skills Plus approach emphasizes that the skills are complemented by understanding of subject, meta-cognition and personal qualities. Later, Pool and Sewell (2007) introduced the "CareerEDGE" model where career development, work-life experience, subject understanding and skills, generic skills and emotional intelligence are comprised of the core of the model. Also, self-efficacy, self-confidence and self-esteem were other elements of this model that was 
supported by reflection and evaluation. More recently, career management skills have been in frequent discussion among researchers (Bridgstock, 2009; Jackson \& Wilton, 2016; Tomlinson, 2017). Tomlinson (2017) developed the Capital approach departing from other approaches where "skills" were at the core.

\section{What is Graduate Capital?}

According to Tomlinson (2017), GC is the potential of a graduate to become employable. GC covers five capital domains: Human Capital, Social Capital, Cultural Capital, Psychological Capital and Identity capital. Human Capital is the technical skills, experience and employability skills possessed by someone (Astin \& Sax, 1998; Cotton 1993; Easterling \& Rudell, 1997). Social Capital covers areas such as networking, team working and collaboration with others (Astin \& Sax, 1998; Clarke 2017; Coleman 1988). Cultural Capital covers cultural knowledge, cultural fit, and alignment with values (Cook, Faulconbridge, \& Muzio 2012; Kalfa \& Taksa 2015). Psychological Capital covers qualities such as resilience, adaptability and self-efficacy (Easterling \& Rudell 1997; Yeh, 2010). Identify capital cover the ability of someone to present and project him/herself positively and the ability to create a personal brand (Holmes, 2013; Jackson 2016).

\section{What is Service-Learning?}

Service Learning is a novel pedagogical or andragogical strategy that promotes learning by providing a service to a community. In SL, both the giver and the receiver of the service are benefited. According to Giles and Eyler (1994), SL was first coined by Robert Sigmon and William Ramsey in 1967. The theoretical roots of SL stem from the work of John Dewey that is based on the concepts of experiential learning. Kolb's model for intuitive learning is built on the work of Dewey, Lewin and Piaget. "Taken together, Dewey's philosophical pragmatism, Lewin's social psychology, and Piaget's cognitive developmental genetic epistemology form a unique perspective on learning and development" (Kolb, Boyatzis, and Mainemelis, 2001, p.2). "Service-Learning is a form of experiential education in which students engage in activities that address human and community needs together with structured opportunities intentionally designed to promote student learning and experience” (Jacoby, 1996, p. 5).

There is a lacuna of studies on SL in Sri Lankan context. In other past studies of SL, some theorists argue that Kolb's experiential learning theory doesn't adequately consider the contextual and social aspects of experiential learning (Fenvick 2003). Also, some studies follow Mezirow's (1990) conceptual framework of transformational learning theory that requires further testing being a young theory. Therefore, there is no clear consensus on the theoretical foundation that can be used for SL. Tomlinson's (2017) GC conceptual framework has consisted of five distinct capitals. However, there is no clear boundary between the capitals as attributes of the capitals seem to overlap (Côté, 2005; Jeannotte, 2003).

There is a question of whether participating students of SL projects chose the projects on their own and whether the SL projects were linked to the academic curriculum (Celio et al., 2011). SL studies are largely timeconsuming and often involve small sample sizes from a single institute (Bialka \& Havlik, 2016; Cress et al., 2010). In some studies, the data is self- reported and not been triangulated by the others such as teachers. Also, some studies are affected by selection bias in choosing respondents.

\section{Methodology}

The researcher examined the influence of SL on GC for graduates from state universities in Sri Lanka. In doing so, two key issues needed to be resolved. Firstly, election of the 
methodology should consider that SL is a young andragogical approach to the world and to Sri Lanka and that GC is also a novel concept. Secondly, since there are many community-related work that are carried out by university students, a definition for SL for the researched student activities must be articulated.

Studying on the learning gained by the students following a university course and examining the enhancement of employability potential are broad and complex topics. Therefore, such studies require the exploration of contextual aspects. Service Learning is new in the university curriculum in Sri Lanka. Therefore, there is little knowledge and understanding of SL as well as GC. Contextual understanding aspects are less effectively grasped by quantitative approach (Guba \& Lincoln, 1994; Gummesson 2000; Hammersley 2008). Also, as the purpose of the study also is to construct a theoretical framework; therefore, a suitable method will be required. Therefore, looking at the characteristics of this research, a qualitative approach has been deemed suitable for this research.

According to Benbasat, Goldstein and Mead (1987), in situations with contemporary events and issues in natural setting, case study approach would be applicable. Also, since there aren't many studies in the area of SL and GC, the data could come through theoretical sampling in grounded theory. As Merriam (2001) and Yin (2014) suggest case studies can be combined with other research strategies. In the current research, the case study method is combined with grounded theory according to the grounded case study method as suggested by Eisenhardt (1989), who embedded case studies in Straussian Grounded Theory.

The study flows in three distinct phases where the first phase envelops the preunderstanding of the researcher and the literature reviews on SL and GC. The second phase of the research is the core research and analysis phase that is split into three sub segments. Theoretical sampling was adopted in this phase of the study were inputs of the previous stage respondents were used to determine the respondents of the subsequent stage. In the first segment, a web content search was carried out to identify Sri Lankan state universities that are offering SL courses. As an outcome of this search four SL courses carried out by three universities were identified. The academics who conduct selected SL courses were interviewed to understand the attributes of the SL courses. However, not all the courses under the label of SL qualify as Academic SL based on the definitions articulated by Furco (1996) and Howard (2001). Based on the inputs of the academics of selected SL course, the researcher gathered the list of employers who hire the students that follow SL course of the university. In the second segment, eight identified employers were interviewed to explore on the GC attributes for respective organizations - the attributes that are assessed by the employers in selecting graduate students for employment. GC attributes in comparison with the model of Tomlinson (2017) were identified. In the third segment, students of the selected SL course/courses were interviewed to assess the extent of enhancement of predefined GC attributes as a result of them following the given SL program. The third phase of the current study is dedicated to three major outputs from the study 1) Definition of SL as practiced in a selected course, 2) Definition of GC for selected Corporates and 3) Contribution of SL for enhancing GC in the given case.

Semi-structured interview questionnaires according to the Straussian Grounded Theory (1987) was used to guide interviews with the respondents. The collected data was analyzed using open coding initially and then with support of axial and selective coding.

The current study answers three research questions a) What is the definition of Service Learning as practiced in Sri Lanka b) What is 
the definition of Graduate Capital as perceived by employers in Sri Lanka c) How does Service Learning contribute to enhance Graduate Capital in the context of Sri Lanka.

\section{Findings and Discussion}

Whilst there are several similarities between the SL programs found in literature including course based, credit based or with a structure for reflection (Celio et al., 2011), in answering the three research questions above, the current study revealed that SL program under study featuring a several unique attributes. Similarities between current study and others include the following: credit based course structure where 8 academic credits have been allocated in the case studied; opportunities for reflective learning - where the structure of the course supporting a 5 to 6 months of course duration with many opportunities to reflect; benefits for receiver and the giver - where the SL projects are focused on delivering community needs as well as providing opportunities for the students to learn and sharpen their skills. These similarities are in accordance with the SL program features described by Bringle \& Hatcher (1999). Unique features of the current study are as stated next. Firstly, objective of the SL course itself is enhancing employability of the graduates; Secondly, There is a close collaboration between corporate sponsors and the university in delivering the SL program; Thirdly, coaching and mentoring activities support delivering the program objectives; Fourthly, the selectin of SL project and the project teams are voluntary by the students.

Graduate Capital model of Tomlinson (2017), is a novel conceptual model that preceded the skills approach of (Cotton, 1993), Career EDGE model of Knight and Yorke (2002), The Graduate Capital model constructed based on the feedback of employers interviewed included common capitals such as Human Capital, Social Capital, Cultural Capital, Psychological
Capital, and Identity Capital. As one of the Human Resources directors explained "I would say the five constructs (Capitals) are relevant to any level of hiring - not only graduates (E2L25-27)”. Following other attributes were identified by Sri Lankan Employers as unique compared to the findings in the literature. Firstly, Physical Health and Creativity are recognized as attribute of Human Capital. Increase of noncommunicable diseases in the world has made the focus on health more relevant (Engelgau, Okamoto, Navaratne \& Gopalan, 2010). Creativity, that has been argued by Chawla \& Lenka (2018) as a key ingredient in surviving in ever changing world has been identified as concept that is linked to Human Capital. Walberg and Stariha (1992) has proved the link between creativity and Human Capital. Secondly, Leadership Capital was recognized by the employers as an attribute of GC. Although Political Leadership has been mostly referred to in Leadership capital, Ulrich (2015) introduced a Leadership Capital index that combines organizational leadership and individual leadership. Thirdly, all the six individual capitals of Graduate Capital of the study were found to be influencing each other. In the literature such interplay has been found (Côté,2005; Larson \& Luthans, 2006; Nepstad \& Bob, 2006; Novicevic, \& Harvey, 2004; Nagoma \& Ntale, 2016; Wood \& Wood, 1996).

Regarding enhancement of GC following taking part in SL in the context of Sri Lanka, the study revealed that SL enhances the attributes of GC. This provides opportunities or SL to be included in university curricula.

\section{Conclusion}

The employability of university graduates is a concern of numerous stakeholders, including the educational policymakers, universities, students, and employers. There is much criticism against stakeholders for not focusing efforts on employability within tertiary education. The current study on the 
influence of SL over GC defines the features of a SL program that is conducted in Sri Lanka and the GC attributes of Employers who hire the students that follow the identified SL program. Accordingly, it was found that the GC attributes are enhanced by taking part in the SL program under study. In the main study the researcher has also presented an agenda and a framework for including SL as an andragogical strategy for enhancing GC of university students.

There were several delimitations and limitations to this study. A key delimitation is limiting the study to SL courses in state universities. Also, input of employers to capture the GC was delimited to eight employers based on the feedback of four academics who are involved in SL program. As limitations, Service-Learning programs with the academic SL criteria was offered only in one state university, the batch size of the program was 21 students and time allocated for interviews of the students was 30 minutes each.

Since SL and GC are new areas of study, more studies on the topics would be required. Since the current study focuses on one case, more such cases would be required to validate the outcomes. The current study has studied the academic courses of state universities with the label of "Service Learning”. Further research can be conducted on similar programs with other course names to see whether such courses possess attributes of Academic Service Learning. Whilst the current study focuses on tertiary level of education in state universities, new researches can be conducted on other levels of education and other types of institutes. The GC attributes in the current study are based on the inputs of employers who hire students who follow the identified SL course. The GC attributes can be validated with other employers in Sri Lanka too.

\section{References}

Ariyawansa, R. G. (2008). Employability of Graduates of Sri Lankan Universities. Sri Lankan Journal of Human Resource Management, $\quad 1(2)$ DOI: http://doi.org/10.4038/sljhrm.v2i1.5107

Astin, A.W., \& Sax, L.J. (1998). How undergraduates are affected by service participation. Journal of Collage Student Development, 39(3), 251-263. DOI: https://digitalcommons.unomaha.edu/slcehig hered/7

Bathmaker, A. M., Ingram, N., \& Waller, R. (2013). Higher education, social class and the mobilisation of capitals: Recognising and playing the game. British Journal of Sociology of Education, 34(5-6),723-743. DOI:

https://doi.org/10.1080/01425692.2013.8160 41

Begel, A., \& Simon, B. (2008). Struggles of new college graduates in their first software development job. In Proceedings of the 39th SIGCSE technical symposium on Computer science education (pp. 226-230). DOI: https://doi.org/10.1145/1352135.- 1352218

Benbasat, I., Goldstein, D. K., \& Mead, M. (1987). The case research strategy in studies of information systems. MIS quarterly, 369386. DOI: https://doi.org/10.2307/248684

Bialka, C.S., \& Havlik, S. A. (2016). Partners in Learning: Exploring two transformative university and high school Service-Learning partnerships; Journal of experiential education, 36 (3), 220-237. DOI: https://doi.org/10.1177/1053825916640539

Bringle, R.G., \& Hatcher, J.A. (1999). Reflection in Service Learning: making meaning of Experience. Educational horizons, Summer, 179-185., fall, 112-122. DOI: https://doi.org/10.1080/87567559709596221 
Bridgstock, R. (2009). The graduate attributes we've overlooked: Enhancing graduate employability through career management skills. Higher Education Research \& Development, 28(1), 31-44. DOI:

https://doi.org/10.1080/07294360802444347

Brown, P., Hesketh, A., \& Williams, S. (2003). Employability in a knowledge-driven economy. Journal of education and work, 16(2), 107-126. DOI: https://doi.org/10.1080/13639080305562

Celio, C.L., Durlak, J., \& Dymnicki, A. (2011). A Meta analysis of the Impact of SL on Students. Journal of Experiential Education, 34(2), 164-181. DOI: https://doi.org/10.1177/10538259110340020 5

Chawla, S., \& Lenka, U. (2018). Leadership in VUCA environment. In Flexible strategies in VUCA markets (pp. 213-224). Springer, Singapore.

DOI: https://doi.org/10.1007/978-981-10-89268_16

Clarke, M. (2017). Rethinking graduate employability: the role of capital, individual attributes and context. Studies in Higher Education, 1-15. DOI: https://doi.org/10.1080/03075079.2017.1294 152

Coleman, J. S. (1988). Social capital in the creation of human capital. American journal of sociology, 94, S95-S120. DOI: https://doi.org/10.1086/228943

Cook, A. C., Faulconbridge, J. R., \& Muzio, D. (2012). London's legal elite:recruitment through cultural capital and the reproduction of social exclusivity in City professional service fields. Environment and Planning A, 44(7), 1744-1762. DOI: https://doi.org/10.2139/ssrn.2321031
Côté, J. E. (2005). Identity capital, social capital and the wider benefits of learning: generating resources facilitative of social cohesion. London review of education, 3(3), 221-237.

DOI: https://doi.org/10.1080/14748460500372382

Cotton, K. (1993). Developing employability skills. Northwest Regional Educational Research Laboratory, Portland. Retrieved from

https://educationnorthwest.org/sites/default/ files/DevelopingEmployabilitySkills.pdf

Cress, C.M., Yamashita, M., Duarte, R., \& Burns, H. (2010). A transnational comparison of service learning as tool for leadership development. International journal of organizational analysis. 18(2), 228-244.

DOI: https://doi.org/10.1108/19348831011046281

Easterling, D., \& Rudell, F. (1997). Rationale, benefits and methods of service learning in marketing education. Journal of Education for Business, 73(1), 58-62. DOI: https://doi.org/10.1080/08832329709601617

Eisenhardt, K. M. (1989). Building theories from case study research. Academy of management review, 14(4), 532-550. DOI: https://doi.org/10.5465/amr.1989.4308385

Engelgau, M., Okamoto, K., Navaratne, K. V., \& Gopalan, S. (2010). Prevention and control of selected chronic NCDs in Sri Lanka: policy options and action. World Bank, Washington, DC. DOI: https://doi.org/10.1596/9780821387245_ch0 5

Fenwick, T. J. (2003). Learning through experience: Troubling orthodoxies and intersecting questions. Malabar, FL: Krieger. Retrieved from http://hdl.voced.edu.au/10707/42954.

Fejes, A. (2010). Discourses on employability: constituting the responsible 
Wijayanama, C., Ranjani, R.P.C., Mohan, D.U., KJM, 2021, 10 (01)

citizen. Studies in continuing education, 32(2), 89-102. DOI: https://doi.org/10.1080/0158037x.2010.4883 53

Finch, D.J., Hamilton, L.K., Baldwin, R., \& Zehner, M. (2013). An exploratory study of factors affecting undergraduate employability. Education + Training, 55(7), 681-704. DOI: https://doi.org/10.1108/et-072012-0077

Furco, A. (1996). Expanding boundaries: Serving and learning. Corporation for national service. Washington, DC: Cooperative Education Association.

Garsten, C., \& Jacobsson, K. (2004). Learning to be employable: new agendas on work, responsibility, and learning in a globalizing world. Palgrave MacMillan.

Gibbons, R., \& Waldman, M. (2004). Taskspecific human capital. American Economic Review, 94(2), 203-207. DOI: https://doi.org/10.1257/0002828041301579

Giles Jr, D. E., \& Eyler, J. (1994). The theoretical roots of service-learning in John Dewey: Toward a theory of servicelearning. Michigan Journal of Community Service Learning, 1(1), 7. Retrieved from https://digitalcommons.unomaha.edu/cgi/vie wcontent.cgi?article $=1152 \&$ context $=$ slceslg en

Guba, E. G., \& Lincoln, Y. S. (1994). Competing paradigms in qualitative research. Handbook of qualitative research, 2(163-194), 105. Retrieved from http://ankara.lti.cs.cmu.edu/11780/sites/defa ult/files/10-guba_lincoln_94.pdf

Gummesson, E. (2000). Qualitative Methods in Management Research. London: Sage Publications. https://doi.org/10.1002/jsc.512
Hammersley, M. (2017). Deconstructing the qualitative-quantitative divide 1. In Mixing methods: Qualitative and quantitative research (pp 39-55). Routledge. DOI: https://doi.org/10.4324/9781315248813-2

Harvey, L. (2001). Defining and measuring employability. Quality in higher education, 7(2), 97-109. DOI https://doi.org/10.1080/13538320120059990

Hillage, J., \& Pollard, E. (1998). Employability: developing a framework for policy analysis. London. Retrieved from https://www.voced.edu.au/content/ngv:4035 2

Howard, J. (2001). Service-learning course design. Workbook. Michigan, Edward Ginsberg Center for Community Service, The University of Michigan. Retrieved from https://files.eric.ed.gov/fulltext/ED457774.p df

Holmes, L. (2013). Competing perspectives on graduate employability: possession, position or process?. Studies in Higher Education, 38(4), 538-554. DOI: https://doi.org/10.1080/03075079.2011.5871 40

Jackson, D., \& Wilton, N. (2016). Developing career management competencies among undergraduates and the role of work-integrated learning. Teaching in Higher Education, 21(3), 266-286. DOI: https://doi.org/10.1080/13562517.2015.1136 281

Jacoby, B. (1996). Service-Learning in Higher Education: Concepts and Practices. The Jossey-Bass Higher and Adult Education Series. Jossey-Bass Publishers, 350 Sansome St., San Francisco, CA 94104.

Jayasundara, N. S. (2014). Higher Education Policy in Sri Lanka: Implementation in State Universities. Scientific Research Journal, 2(2), 41-44. Retrieved from 
Wijayanama, C., Ranjani, R.P.C., Mohan, D.U., KJM, 2021, 10 (01)

http://www.scirj.org/papers-0214/scirj-

P021499.pdf

Kalfa, S., \& Taksa, L. (2015). Cultural capital in business higher education: reconsidering the graduate attributes movement and the focus on employability. Studies in Higher Education, 40(4), 580-595. DOI: https://doi.org/10.1080/03075079.2013.8422 10

Knight, P. T., \& Yorke, M. (2002). Employability through the curriculum. Tertiary education and management, 8(4), 261-276. DOI: https://doi.org/10.1080/13583883.2002.9967 084

Kolb, D. A., Boyatzis, R. E., \& Mainemelis, C. (2001). Experiential learning theory: Previous research and new directions. Perspectives on thinking, learning, and cognitive styles, 1(8), 227-247. DOI: https://doi.org/10.4324/9781410605986-9

McQuaid, R. W., Green, A., \& Danson, M. (2005). Introducing employability. Urban Studies, 42(2), $\quad$ 191-195. DOI: https://doi.org/10.1080/0042098042000316092

Jeannotte, M. S. (2003). Singing alone? The contribution of cultural capital to social cohesion and sustainable communities. The International Journal of Cultural Policy, 9(1), 35-49. DOI: https://doi.org/10.1080/10286630320000895 07

Joseph, M., Stone, G.W., Grantham, K., Harmancioglu, N., \& Ibrahim, E. (2007). An exploratory study on the value of service learning projects and their impact on community service involvement and critical thinking, Quality Assurance in education, 15(3), 318-333. DOI: https://doi.org/10.1108/09684880710773192
Larson, M., \& Luthans, F. (2006). Potential added value of psychological capital in predicting work attitudes. Journal of leadership \& organizational studies, 13(1), 45-62.

DOI: https://doi.org/10.1177/10717919070130010 701

Merriam, S. B. (2002). Introduction to qualitative research. Qualitative research in practice: Examples for discussion and analysis, 1(1), 1-17. Retrieved from https://stu.westga.edu/ bthibau1/MEDT\%20 8484-

\%20Baylen/introduction_to_qualitative_rese arch/introduction_to_qualitative_research.pd $\mathrm{f}$

Mezirow, J. (1990). How critical reflection triggers transformative learning. Fostering critical reflection in adulthood, 1, 20. Retrieved from http://lecticalive.s3.amazonaws.com/assets/p $\mathrm{df} /$ learning/Mezirow-critical-reflection.pdf

Mourshed, M., Patel, J., \& Suder, K. (2014). Education to employment: Getting Europe's youth into work. McKinsey \& Company. Washington DC

Nepstad, S., \& Bob, C. (2006). When do leaders matter? Hypotheses on leadership dynamics in social movements. Mobilization: An International Quarterly, 11(1), 1-22. DOI: https://doi.org/10.17813/maiq.11.1.0133136 $00164 \mathrm{~m} 727$

Ngoma, M., \& Dithan Ntale, P. (2016). Psychological capital, career identity and graduate employability in Uganda: the mediating role of social capital. International Journal of Training and Development, 20(2), 124-139.

DOI: https://doi.org/10.1111/ijtd.12073

Novicevic, M. M., \& Harvey, M. G. (2004). The political role of corporate human resource management in strategic global 
Wijayanama, C., Ranjani, R.P.C., Mohan, D.U., KJM, 2021, 10 (01)

leadership development. The Leadership Quarterly, 15(4), 569-588. DOI: https://doi.org/10.1016/j.leaqua.2004.05.008

Paadi, K. (2014). Perceptions on employability skills necessary to enhance human resource management graduates prospects of securing a relevant place in the labour market. European Scientific Journal. Special Edition, 129-143. Retrieved from https://citeseerx.ist.psu.edu/viewdoc/downlo ad?doi=10.1.1.685.6416\&rep=rep1\&type=p df\#page $=141$

Pool, L. D., \& Sewell, P. (2007). The key to employability: Developing a practical model of graduate employability, Education + Training, 49(4), 227-289. DOI: https://doi.org/10.1108/00400910710754435

Simonet, D. (2008). Service-learning and academic success: The links to retention research. Minnesota Campus Compact, 1(1), 1-13. Retrieved from http://www.mncampuscompact.org/wpcontent/uploads/large/sites/30/2016/04/Servi ce-Learning-and-Academic-Success1.pdf

Sumanasiri, E. G. T., Ab Yajid, M. S., \& Khatibi, A. (2015). Review of literature on graduate employability. Journal of Studies in Education, 5(3), 75-88. DOI: https://doi.org/10.5296/jse.v5i3.7983

Tomlinson, M., \& Tomlinson, M. (2017). Forms of graduate capital and their relationship to graduate employability. Education+ Training, 59(4), 338-352. DOI: https://doi.org/10.1108/et-05-2016-0090

Ulrich, D. (2015). The leadership capital index: Realizing the market value of leadership. Berrett-Koehler Publishers. DOI: https://doi.org/10.5848/bk.978-1-62656600-2_5

Walberg, H. J., \& Stariha, W. E. (1992). Productive human capital: Learning, creativity, and eminence. Creativity
Research Journal, 5(4), 323-340. DOI: https://doi.org/10.1080/10400419209534445

Wickramasinghe, V., \& Perera, L. (2010). Graduates', university lecturers' and employers' perceptions towards employability skills. Education+ Training, 52(3), 226-244. DOI: https://doi.org/0.1108/00400911011037355

Wood, D., \& Wood, H. (1996). Vygotsky, tutoring and learning. Oxford review of Education, 22(1), 5-16. DOI: https://doi.org/10.1080/0305498960220101

Yeh, T. L. (2010). Service-Learning and Persistence of Low-Income, First-Generation College Students: An Exploratory Study. Michigan Journal of Community Service Learning, 16(2), 50-65. Retrieved from https://files.eric.ed.gov/fulltext/EJ904634.pd $\mathrm{f}$

Yin, R. K. (2014). Case study research: design and methods 5th ed. Sage publications, Thousand Oaks. CA. DOI: https://doi.org/10.3138/cjpe.30.1.108 